\title{
Thinking out of the exams box: assessment through talk?
}

by Valerie Coultas, Kingston University

As written exams become the dominant mode of testing there is less time for thought about other forms and modes of assessment. This paper argues that re-establishing the importance of assessment through talk, speaking and listening, would not only promote good teaching but also signify a completely different approach to assessment. This approach would empower both pupils and teachers.

Oral assessment has been used in schools for many years. In nearly every lesson a teacher uses questions, at some point, to establish whether or not the pupils understand the topic or concept being taught. Drama teachers use evaluation of role plays, improvisation and performance to teach their subject. Modern Language and English GCSEs have also assessed the quality of pupil talk. Modern Languages has separate attainment targets for speaking and listening. English assessed speaking and listening as one attainment target at GCSE until the new English Curriculum (DfE, 2013a) was introduced and now, although the curriculum still requires teachers to assess spoken language, the oral grade no longer contributes to the final GCSE English grade.

Until recently, the English Literature AQA GCSE also assessed pupils understanding of literature through talk. The oral response option allowed the teacher to interrogate the pupils closely to ensure they had studied the play or novel at a deep enough level to be awarded a particular grade. Through a presentation or a discussion the pupil had to show, for example, understanding or insight into dramatic action, characters, setting, context or themes. The Media Studies GCSE also has practical assignments that can include assessment through talk for example if the pupils are asked to simulate a news team to create a radio news programme. When working as a Head of English, I found that pupils enjoyed the challenge of these oral assignments and felt an immediate sense of accomplishment on completion of such oral tasks. (Coultas, 2006).

Prior to the National Curriculum (1990) there was much greater flexibility in the use of oral assessment for all exams. The CSE mode 3 and the Certificate of Extended Education were exams devised by teachers and there was more opportunity to include oral assessment modules in a range of subjects.

The Cox Report (1989), which informed the first English National Curriculum, did not in fact advocate the kind of rigid, written SATS and exams that have been imposed on children and the teaching profession. This report suggested that teachers should choose from a bank of SATS covering the three attainment targets. In primary schools, Cox (1991) suggested, that pupils responses should be mainly oral or practical unless the target required some writing or graphical work. The original report suggested that the task should be conducted over an extended period and should reinforce teaching and learning and not be a bolt on activity. Cox also suggested that coursework should have a major input into the assessment process. (Cox, 1995). 
What a difference between this and the present testing regime? Why did we move from some reasonably sane educational ideas to the dreadful, dreary SATS and exam papers? How come speaking and listening has once again become the Cinderella strand and been down graded in the new GCSE English exam? (DfE, 2013b).

The reason is very simple. Speaking and listening and assessing reading aloud have to rely on teachers' judgements and neither the Conservative led coalition nor New Labour will allow teachers to make the really important judgments on pupils. Speaking and Listening is the educational casualty of the drive towards centralisation. If you want to raise standards from the centre, using crude league tables to name and shame, you have to have standardised written papers. The political imperative drives the educational agenda not the needs of the pupils and good teaching practice.

This agenda helped to influence the National Literacy Strategy (1998) which originally gave little direct advice on teaching speaking and listening and drama at key stage one and two. The operating definition of literacy in the strategy was reading and writing because this was what would be tested in the exams.

The present exams in the Cultural Restorationist English curriculum (Coultas, 2013) remain highly traditional written tests however and this, quite naturally, directs the energy of most schools away from oral assessment even if teachers have tried to maintain it as part of their lesson pedagogy. At 7, for example, teachers in the past would listen to the child read aloud to make a judgement about their decoding skills, their fluency and comprehension. This is exactly what the first three levels of Attainment target two, reading, are framed aroundjudgements on accuracy, fluency, understanding. Which is the most appropriate form for that judgement to be made? A Phonics test or reading aloud? The answer is obvious. What other ways could speaking and listening be used in Maths and English at this age? It is clear that primary school teachers could create a much better, more rounded, developmental assessment at this age than the present screening test for phonics, if they were allowed to.

At 11 and 14 it would be quite possible to develop an assessment based on speaking and listening, drama or group work that tested reading, response to literature and writing based on the idea of a controlled assignment. A teacher, after studying a text, might choose for example writing in role as a character, prepared by a speaking and listening activity such as hot seating. This involves assessing all the attainment targets in one assignment but it is linked to good practice in teaching the pupils to plan their writing and will therefore help the students to produce their best piece of writing. The assessment is integral to the teaching.

The added bonus of this approach is that these types of assessments in the primary and secondary phase would tell the teacher a lot more about the pupil's potential and make it possible to give accurate feedback on how to improve. Such assessments stimulate collaborative thinking and encourage originality, evaluation and problem solving. These higher order skills are valued in the workplace and will help pupils to enter the adult world with more social and academic confidence. 
There is no reason why every subject could not adopt an oral component as part of the system of assessment. When working as a senior teacher, teachers were encouraged to use these more inventive forms of assessment during the school assessment week, each half-term. Why not get the pupils to demonstrate their ICT skills through their own presentation of a topic to the rest of the group? Why not arrange a debate with pupils as $19^{\text {th }}$ century politicians on votes for women? Why cannot a particular painting be researched, analysed and introduced to the class by the students, rather than the art teacher? Such activities can create memorable learning moments for students. Students learn more by finding out and teaching others than they do by just being filled with information. Students will listen closely to their peers, particularly when they know that a lot of preparation has taken place beforehand.

Let's start thinking out of the exams box and use our knowledge of what really constitutes good teaching and learning to create wider and more developmental forms of assessment. Can't we get the pupils talking about what they know rather than always having to write it down? Can't we use good forms of formative assessment whatever we are told to do from above?

Cox, B (1991) Cox on Cox: An English Curriculum for the 1990s Hodder and Stoughton Cox, B (1995) Cox on The Battle for The English Curriculum Hodder and Stoughton Coultas, V (2006b) 'Investigating Talk in Challenging Classrooms-boys enjoy the power of talk' English in Education 40 (2 summer) pp 41-55

Coultas, V (2013b) English for the Few or English for the Many? Ainley, P and Allen, M (Eds) Education Beyond the Coalition - reclaiming the agenda London: Radicaled DES and the Welsh Office (1989) English for ages 5-16 (The Cox Report) HMSO

DES (1990) English in the National Curriculum HMSO

DFES (1998) The National Literacy Strategy Framework for Teaching Cambridge University Press

DfE (2013) Programme of Study for English Key Stage Four http://media.education.gov.uk/assets/files/pdf/e/english\%20-\%20key\%20stage \%204\%2005-02-13.pdf accessed July $26^{\text {th }} 2013$

DfE (2013) GCSE English Language http://media.education.gov.uk/assets/files/pdf/e/english\%20$\% 20$ key $\% 20$ stage $\% 204 \% 2005$ 0213.pdfhttps://www.gov.uk/government/uploads/system/uploads/attachment data/file/206143/GCSE English Language final.pdf accessed June $30^{\text {th }} 2013$ 